\title{
The organizational-pedagogical activity of the kharkiv state teachers' institute in the post-war period
}

\author{
Bondarenko A.* \\ H.S. Skovoroda Kharkiv National Pedagogical University, Kharkiv, Ukraine
}

Received: 22.03.2019 Accepted: 15.04.2019

\begin{abstract}
The organizational-pedagogical activity of the Kharkiv State Teachers' Institute in the post-war period were revealed in the article. And the features of educational, organizational-pedagogical research, ideological and educational work and staffing were discovered; Then the advantages and disadvantages in the work of the teacher's institute in the specified period were outlined. General scientific and historical-pedagogical methods of research (analysis, synthesis, comparison) have been used for achievement of the set goal, which are allowed to systematize historical and pedagogical sources, reference literature. Moreover the leading trends were identified in the development of the Kharkiv state teacher as an independent structural unit. It was established that in 1935, with the Resolution of the People's Commissars of the Ukrainian SSR "On the Training of Pedagogical Personnel, Systems of Pedagogical Education and Networks of Pedagogical Institutions". It had four departments (faculties): physical and mathematical, natural-geographical, historical and linguistic-literary. . In the postwar period, the problem of the lack of skilled personnel in educational institutions, especially in schools, was rather acute in front of the Soviet authorities. Therefore, the Kharkiv State Teachers' Institute was called to fulfill the tasks of qualitative and short-term (2 years) teacher training for 5-7 grades, brought up in the spirit of communist ideology. So Kharkov state pedagogical institute was designed to do the job quality and short-term (2 years) teacher training for 5-7 classes, educated in the spirit of communist ideology. According to the order of the Minister of Higher Education of the USSR S. Kaftanov "On the separation of the Kyiv, Kharkiv and Odessa Teachers 'Institutions into Independent Institutes" from May 25, 1946, a new stage of the organizational and pedagogical activity began of the "Kharkiv State Teachers' Institute" as independent higher pedagogical educational institution. On the basis of the study of historical-pedagogical literature and archival documents, the theoretical positions are systematized and the experience of organizational-pedagogical activity of the Kharkiv State Teachers' Institute is systematized for the use of progressive achievements in the context of the reform of higher pedagogical education in Ukraine.
\end{abstract}

Key words: teacher's institute, totalitarian regime, ideology, decree, reorganization, teacher education, public education system, organizational and pedagogical activity, Kharkiv State Teacher's Institute, pre-war period.

\section{Організаційно-педагогічна діяльність харківського державного учительского інституту в повоєнний період \\ Бондаренко А. С.}

Харківський національний педагогічний університет ім. Г.С. Сковороди, Харків, Україна

\begin{abstract}
Анотація. У статті розкрито організаційно-педагогічну діяльність Харківського державного учительського інституту в повоєнний період; виявлено особливості навчальної, науково-дослідної, ідейно-виховної роботи; кадрової; окреслені позитиви і недоліки в роботі учительського інституту в зазначений період. Для досягнення поставленої мети було використано загальнонаукові та історико-педагогічні методи дослідження (аналіз, синтез, порівняння), які дозволили систематизувати історико-педагогічні джерела, довідкову літературу; визначили провідні тенденції розвитку Харківського державного учительського інституту, як самостійної структурної одиниці. Установлено, що в 1935 р. згідно з Постановою Раднаркому УРСР «Про підготовку педагогічних кадрів, систему педагогічної освіти та мережу педагогічних установ» при Харківському державному педагогічному інституті створюється дворічний учительський інститут. Він мав чотири відділи (факультети): фізико-математичний, природничо-географічний, історичний і мовно-літературний. У повоєнний
\end{abstract}

\footnotetext{
Corresponding Author: Bondarenko Anna Stanislavivna. Phone: +38(050) 630-23-44. E-mail: annabond.79@ukr.net H.S. Skovoroda Kharkiv National Pedagogical University, lane Surikova, 27, Kharkiv, Ukraine, 61093.

Biдnовідальний автор: Бондаренко Анна Станіславівна. Тел. +38(050) 630-23-44. E-mail: annabond.79@ukr.net Харківський національний педагогічний університет ім. Г.С. Сковороди, пров. Сурикова, 27, м. Харків, Україна, 61093.
} 
період перед органами радянської влади досить гостро постала проблема нестачі кваліфікованих кадрів у закладах освіти, особливо у школах. Тому Харківський державний учительський інститут був покликаний виконати завдання якісної і короткотермінової (2 роки) підготовки вчителів для 5-7 класів, вихованих у дусі комуністичної ідейності. Згідно з наказом міністра вищої освіти СРСР С. Кафтанова «Про виокремлення Київського, Харківського і Одеського учительських інститутів в самостійні інститути» від 25 травня 1946 р. розпочався новий етап організаційно-педагогічної діяльності «Харківського державного учительського інституту» як самостійного вищого педагогічного навчального закладу. На основі вивчення історикопедагогічної літератури та архівних документів систематизовано теоретичні положення та узагальнено досвід організаційно-педагогічної діяльності Харківського державного учительського інституту для використання прогресивних надбань в умовах реформування вищої педагогічної освіти в Україні.

Ключові слова: учительський інститут, тоталітарний режим, ідеологія, постанова, реорганізація, педагогічна освіта, система народної освіти, організаційно-педагогічна діяльність, Харківський державний учительський інститут, повоєнній період.

\title{
Организационно-педагогическая деятельность харьковского государственного учительского института в послевоенный период
}

\author{
Бондаренко А. С. \\ Харковский национальний педагогический университет им. Г. С. Сковороды, Харьков, Украина
}

\begin{abstract}
Аннотация. В статье раскрыта организационно-педагогическая деятельность Харьковского государственного учительского института в повоенный период; выявлены особенности учебной, научно-исследовательской, идейно-воспитательной роботы; кадровой; очерчены позитивы и негативы в работе в определенный период. Для достижения поставленной цели были использованы общенаучные и историко-педагогические методы исследования (анализ, синтез, сравнение), которые позволили систематизировать историко-педагогические источники, справочную литературу, определили основные тенденции развития Харковского государственного учительського института, как самостоятельной структурной единицы. Установлено, что в 1935 г., согласно Постановлению Совнаркома УССР «Про подготовку педагогических кадров, систему педагогического образования и сеть педагогических учреждений» при Харьковском государственном институте создается двухгодичный учительський институт. Он имел четыре отделения (факультеты) физико-математический, природо-географический, исторический и языково-литературный. В послевоенный период перед органами советской власти остро возникла проблема нехватки педагогических кадров в учреждениях образования. Харьковский государственный учительский институт должен был выполнить задание по краткосрочной (2 года) подготовке учителей для 5-7 классов, воспитанных в духе коммуниститческой идейности. Согласно приказу министра высшего образования СССР С.Кафтанова «Про отделение Киевского, Харьковского и Одеского учительских институтов в самостоятельные институты» от 25 мая 1946 г. начался новый этап организационно-педагогической деятельности "Харьковского государственного учительского института» как самостоятельного высшего педагогического учебного заведения. На основании изучения историкопедагогической литературы и архивных документов систематизированы теоретические положення и обобщен опыт организационно-педагогической деятельности Харьковского государственного учительского института для использования прогрессивных наработок в условиях реформирования высшего педагогического образования Украины.
\end{abstract}

Ключевые слова: учительский институт, тоталитарный режим, идеология, постановление, реорганизация, педагогическое образование, система народного образования, организационно-педагогическая деятельность, Харьковский государственный учительский институт, послевоенный период.

\section{Bcmyn}

Вирішення складних завдань інтеграції вітчизняної освіти в світовий освітній простір неможливе без ретельного вивчення власного історичного минулого, ознайомлення з педагогічною спадщиною видатних теоретиків і практиків, які стояли біля витоків педагогічної освіти. Це, передусім, потрібно для обґрунтування теоретико-методологічних і організаційних концепцій, систем і технологій учіння, провідне місце серед яких займають педагогічні технології, які мають забезпечувати особистісний розвиток та саморозвиток учителя, його професійну і соціальну мобільність, адаптаційну гнучкість та конкурентоспроможність на ринку праці. Саме тому, звернення до національних історико-педагогічних надбань має вагоме науково-практичне значення і сприяє послідовній, цілеспрямованій професійній підготовці вчителя. 
У пошуках оптимальних шляхів наукового розв'язання визначеної проблеми доцільним є глибоке вивчення й творче осмислення з сучасних позицій діяльності вищих педагогічних закладів України, а саме учительських інститутів в конкретно історичний період. Це дозволяє відстежити історичні тенденції формування змісту і напрямів фахової підготовки майбутніх учителів на різних етапах, співвіднести прогресивний досвід з реаліями сучасності; зберегти національну самобутність вищої педагогічної освіти України.

У площині використання творчих пошуків і доробку вітчизняної педагогічної теорії і практики особливий інтерес викликає організаційно-педагогічна діяльність Харківського державного учительського інституту у повоєнний період.

Mema cmammi. Розглянути організаційно-педагогічну діяльність Харківського державного учительського інституту у повоєнний період, виявити недоліки та позитиви навчальної, науководослідної, ідейно-виховної, кадрової роботи.

\section{II Матеріал і методи дослідження}

У вивченні зазначеної проблеми спиралися на системний підхід, який дозволив вивчати педагогічні фракти, явища і процеси у взаємозв'язку з соціально-політичною системою досліджуваного періоду. Феноменологічний забезпечив можливість представити незаангажований, неідеалізований погляд на сучасну та історичну дійсність, герменевтичний дав можливість інтерпретувати зміст науковопедагогічних праць, наративних джерел тощо.

На основі визначених методологічних підходів використано такі методи дослідження: загальнонауковий забезпечував історико-педагогічний аналіз із узагальненням інформації: архівних матеріалів щодо діяльності навчальних закладів другої половини XIX століття.

\section{III Результати}

Учительські інститути - педагогічні навчальні заклади, які почали створюватися на теріторії Україні, в складі Російської імперії, з другої половини XIX ст. Призначалися вони для підготовки вчителів міських, початкових училищ підвищеного типу. У 1862 році Міністерство народної освіти опублікувало проект Статуту учительських інститутів, офріційно засвідчивши упровадження нового типу педагогічного навчального закладу. [2, с.27]

Зазначимо, що першими учительськими інститутами на українських землях у складі Російської імперії були Глухівський і Феодосійський (1974р.). Вони готували вчителів для народних початкових училищ. Це були прогресивні на той час навчальні заклади, які впроваджували багато позитивного в навчальному процесі: програми теоретичних курсів загальнопедагогічної підготовки в учительських інститутах були авторськими, здійснювався принцип зв'язку навчання з життям, були поширені різні види практики, проводилася позааудиторна робота, впроваджувалися нові форми і методи навчання тощо $[1,7]$.

На початок 30-их pp. XX ст. у кризовому стані перебувала не тільки економіка України, але і освіта. Катастрофрічно не вистачало вчителів у школах республіки, мережа яких зростала значними темпами у зв'язку з уведенням загального обов'язкового навчання. До того ж основний склад учителів був із середньою освітою, рівень професійно-педагогічної підготовки був низьким. Окрім того, характер підготовки вчителів «старої школи» не дозволяв повністю покладатись на них у виконанні ідеологічних завдань, що диктувались новою владою. [5, с. 77]

Проте, незважаючи на певні успіхи, діюча система підготовки вчителів була не в змозі задовільні ти потреби шкіл, структура вищих педагогічних закладів не виконувала вимог, які ставилися до вимог радянського педагога. Для виконання завдань загального забезпечення дітей освітою не вистачало учителів масової школи. Виникла проблема в реорганізації системи педагогічної освіти.

у 1933-1934 навчальному році частина інститутів соціального виховання і професійної освіти реорганізується у педагогічні інститути з чотирьох річним терміном навчання (Київ, Харків, Одеса, Ніжин). Саме при інститутах створювалися учительські інститути, які готували педагогічні кадри для VVII класів. [3, 6] 
У 1935 р. згідно з Постановою Раднаркому УРСР «Про підготовку педагогічних кадрів, систему педагогічної освіти та мережу педагогічних установ» при Харківському державному педагогічному інституті створюється дворічний учительський інститут, який мав денне і заочне відділення. Він мав чотири відділи (фракультети): фрізико-математичний, природничо-географрічний, історичний і мовнолітературний. Харківський державний учительський інститут був покликаний виконати завдання якісної і короткотермінової (2 роки) підготовки вчителів для 5-7 класів, вихованих у дусі комуністичної ідейності. $[4$, c.67]

Згідно з наказом міністра вищої освіти СРСР С. Кафтанова «Про виокремлення Київського, Харківського і Одеського учительських інститутів в самостійні інститути» від 25 травня 1946 р. розпочався новий етап організаційно-педагогічної діяльності «Харківського державного учительського інституту» як самостійного вищого педагогічного навчального закладу.

Перший рік роботи Харківського державного учительського інституту поклав на його колектив особливу відповідальність. Необхідно було розв'язати цілу низку нових питань та здійснити заходи, без яких не можна було починати перший навчальний рік. До таких питань, у першу чергу, належали вибір та устаткування приміщення для інституту, укомплектування кадрами професорсько-викладацького складу, устаткування навчальних приміщень та студентського гуртожитку, забезпечення навчального процесу необхідною матеріальною базою. [9, арк.1]

Вивчення архівних джерел [11, арк. 7; 5, арк. 2] дозволяє констатувати, що одним із напрямів організаційно-педагогічної діяльності інституту стало комплектування навчального закладу педагогічними кадрами. Навчальний процес протягом року був повністю забезпечений професорськовикладацьким складом. Навчальну роботу в учительському інституті проводили штатні викладачі та викладачі за сумісництвом, які працювали, одержуючи 0,5 окладу. Для викладання окремих дисциплін (читання курсів методики викладання української та російської мови і літератури, основ сільського господарства, вступу до мовознавства, історії математики, шкільної гігієни) було запрошено викладачів з погодинною оплатою. Така практика була доцільною через відсутність у повоєнні роки кваліфікованих викладачів з окремих дисциплін і мала тимчасовий характер.

Зауважимо, що викладання окремих методик дозволялося лише тим викладачам, які мали безпосередній досвід роботи в середній школі та протягом року підвищували під керівництвом завідувачів кафедр теоретичну підготовку в галузі методик.

Підвищення наукової кваліфрікації викладацького складу учительського інституту стало визначальним.

3 огляду на це, від початку роботи Харківського державного учительського інституту колектив викладачів було спрямовано на підготовку до складання кандидатських іспитів. Із цією метою було складено план підвищення кваліфікації викладачів інституту на 1946 рік, який розроблявся кафедрами за вказівками науково-навчальної частини Харківського державного учительського інституту і був затверджений на засіданні Вченої ради. У такий спосіб здійснювався і контроль за виконанням плану науково-дослідної роботи. [10, арк.11].

На 1946 рік було затверджено план науково-дослідної роботи інституту. Відповідно до плану, у 1946 році було завершено 5 наукових робіт, намічена розробка 17 наукових тем, 10 з яких повинні бути закінчені в 1947 р.. Більшість з них носила науково-методичний характер (протокол Вченої ради №3 від 22.11.46 p.).

Вивчення архівних джерел [8, арк. 7; 9, арк. 2] дозволяє констатувати, що протягом усього 19461947 начального року робота інституту проводилась в частині будинку Харківської середньої неповної школи №110, де і було розміщено 6 аудиторій та бібліотеку та школі №36. З'ясовано, що план набору студентів на цей навчальний рік було виконано з перебільшенням, проти встановленої Міністерством норми 150 студентів за планом, було зараховано 187 чоловік (протокол Вченої ради №1 від 15.10.46р.).

У Харківському державному учительському інституті існувало чотири відділи (факультети): фрізико-математичний, природничо-географічний, історичний і мовно-літературний.

Навчальна робота проводилась у дві зміни, але це не забезпечувало потреби в чіткій організації навчального процесу. Проте, за наявності 13 академічних груп не вистачало аудиторій, особливо в ті дні, коли проводились практичні і лабораторні заняття з розподілом груп на підгрупи. 
Виконання всіх занять за навчальним розкладом було можливе при використанні додаткових приміщень Харківського педагогічного інституту. У таких умовах не можна було устаткувати власні кабінети та лабораторії, що, звичайно, було серйозною перешкодою у справі підготовки кваліфікованих учителів.

Внаслідок клопотань, які порушував інститут, у червні 1947 р. наказом Міністра освіти УРСР Харківському державному учительському інституту було виділено частину будинку №3 по Фанінському провулку для навчальних аудиторій та гуртожитку.

Протягом 1946-1947 навчального року роботу кафедр було спрямовано на утворення власної навчально-матеріальної бази. До 1 січня 1947 року інститут придбав навчального устаткування для лабораторій і кабінетів на 50264 крб. Станом на 1 липня 1947 року ця сума складала вже 85829 крб., зокрема по кабінету ботаніки - 22951 крб., по кабінету зоології 9043 крб., по лабораторії з хімії - 6606 крб., по лабораторії з фрізики - 27325 крб. Для різних кабінетів протягом року придбано і виготовлено 200 стінних таблиць, необхідних як наочне приладдя [10, арк. 3,4].

У процесі дослідження з'ясовано, що протягом 1946-1947 навчального року навчання відбувалось за новими навчальними планами, які були затверджені для учительських інститутів Управлінням у справах вищої школи при РНК УРСР 17 жовтня року. Практика роботи за цими навчальними планами виявила такі недоліки:

- надмірне збільшення лекційних годин за рахунок практичних занять. Особливо цю хибу помітно на таких дисциплінах, як історія середніх віків, географія УРСР, російська і українська літератури. Слід вважати за недолік те, що за навчальними планами були зовсім не передбачені практичні заняття 3 таких дисциплін, як психологія, методика викладання математики;

- надмірна кількість іспитів та заліків, нерівномірний їх розподіл по семестрах.

- перевантаження навчального часу ідейно-політичним вихованням, великою кількістю годин, що відведені на вивчення заполітизованих дисциплін. В учительському інституті за окремим планом проводилась політико-виховна робота, спрямована на реалізацію партійних рішень [9, арк. 15] .

У процесі дослідження встановлено, що протягом 1946-1947 навчального року в інституті проводилось комплектування бібліотеки.

На початку року в бібліотеці Харківського державного учительського інституту було лише 1000 томів, які було передано педагогічним інститутом. На 1 січня 1947р. книжковий фонд бібліотеки складав 4800 томів та 650 примірників різних брошур загальною вартістю 83 940. На 1 липня 1947 р. книжковий фронд вже складався з 7325 томів та 1208 примірників брошур загальною вартістю 116684 крб. Водночас бракувало підручників з педагогіки та психології. Бібліотека одержувала за передплатою 64 різних журнали, у тому числі 42 наукових. На 1 липня 1947 року бібліотека мала 427 абонентів, протягом року проведено 7480 книговидач (протокол Вченої ради №2 від 09.10.47р.).

Увесь студентський та викладацький персонал інституту був читачем бібліотеки. Зауважимо, що бібліотека працювала з 9 до 22 години, що свідчило про ії значущість та активну самостійну роботу студентів [10,11]

В аспекті досліджуваної проблеми викликає інтерес той факт, що поряд із недоліками, підготовка майбутніх вчителів супроводжувалась й позитивами: літературні диспути, культпоходи до театрів та кіно, робота у студентських гуртках, активна спортивна діяльність.

Активно працювали і користувалися популярністю серед студентів математичний, мовнолітературний та історичний гуртки, у рамках роботи яких організовувались тематичні конкурси, круглі столи, спільно вивчалось багато додаткової літератури.

Проводились студентські вечори з виступами художньої самодіяльності.

Протягом навчального року, особливо у другому півріччі, студенти розгорнули активну діяльність із випуску стінних газет на кожному факультеті. Також існувала одна загальноінститутська газета «Радянський вчитель».

На першому курсі всіх відділів викладався фракультативний курс «Теорія і практика співів та музики». Мета цього курсу - ознайомлення студентів з музичною грамотою, з класичним творами видатних композиторів, з українським та російським музичним мистецтвом, а також володіння методикою організації дитячого хору у школі. Цей фракультативний курс сприяв піднесенню загальної культури студентів і допомагав майбутнім учителям в організації позакласної роботи у школі. 
Крім цього, на фрізико-математичному відділі успішно були впроваджені дві факультативні дисципліни: історія математики та методика і практика виготовлення наочного приладдя 3 математики $[9,10]$.

Інший напрям організаційно-педагогічної діяльності інституту був спрямований на комплектування навчального закладу педагогічним кадрами.

Навчальний процес протягом року був повністю забезпечений професорсько-викладацьким складом.

Навчальну роботу в учительському інституті проводили штатні викладачі та викладачі за сумісництвом, які працювали, одержуючи 0,5 окладу.

Для викладання деяких дисциплін (читання курсів методики викладання української та російської літератур і мов, основ сільського господарства, вступу до мовознавства, історії математики, шкільної гігієни) було запрошено викладачів з погодинною оплатою. Така практика була доцільною через відсутність у повоєнні роки кваліфікованих викладачів з окремих дисциплін і мала тимчасовий характер.

Зауважимо, що викладання окремих методик дозволялося лише тим викладачам, які мали безпосередній досвід роботи в середній школі та протягом року підвищували під керівництвом завідувачів кафедр свою теоретичну підготовку в галузі методик .

Як свідчать архівні джерела [10, 11, 12], важливим напрямом організаційно-педагогічної діяльності інституту була робота кафедр. Усі вони працювали за планами, що були затверджені навчальною частиною. В основному, робота кафедр була спрямована на підвищення якості викладання. Відповідно до цього кафедри вирішували організаційні питання, проводили навчальнометодичну роботу, роботу з підвищення наукової кваліфікації викладачів, роботу щодо створення власної навчально-матеріальної бази.

Навчально-організаційні заходи кафедр полягали в складанні планів роботи кафедр, перевірці їх виконання, складанні та розгляді робочих планів лекційних курсів та практичних занять, складання планів устаткування кабінетів і лабораторій.

Зазначимо, що особливе місце у підготовці вчителів належало педагогічній практиці.

Педагогічна практика в Харківському учительському інституті проводилась на другому курсі навчання і тривала п'ять тижнів. У досліджуваний період всі заходи по підготовці до педагогічної практики і по ії керівництву здійснювались за укладеним планом роботи, затвердженим дирекцією інституту.

Характерною рисою педагогічної практики було те, що вона проходила під систематичним контролем з боку навчальної частини.

Школи, у яких студенти проходили педагогічну практику, були визначені на початку навчального року, з ними були підписані спеціальні угоди. Це давало змогу планувати всю роботу педагогічної практики заздалегідь.

У школах була проведена робота методистами-керівниками з директорами, завучами, учнями. Кожен директор, завуч і вчитель знав заздалегідь кількість студентів, обсяг роботи з ними через інструкції, які були розіслані до початку практики.

Як свідчать архівні джерела [11, 12], в 1947-1948 навчальному році базовими для проходження педагогічної практики було визначено такі школи : №62, 82, 36, 49, 131, 116, 58, 89. За кожною школою був закріплений представник кафедри педагогіки для керівництва практикою і методист з фізичної підготовки, для якісної методичної допомоги при підготовці уроків з фаху і фрізичної культури.

\section{IV Обговорення}

Процес професійно-педагогічної підготовки в системі загальної підготовки майбутнього вчителя за окремими напрямами став предметом досліджень В. Кузя, П. Гусака, О. Дубасенюк, В. Краєвського, М. Корця, А. Маркової, О. Мороза, О. Пєхоти, Н. Протасової, В. Семиченко, В. Сиротюка, С. Сисоєвої, Л. Сущенко, М. Шеремет та ін.

Теоретико-методологічне обгрунтування процесу загальнопедагогічної підготовки майбутнього вчителя представлене в роботах О. Абдуліної, Ю. Болотіна, В. Бондаря, І. Зязюна, В. Лозової, В. Сластьоніна та ін. 
Наукову цінність для розробки визначеної проблеми мають узагальнюючі праці сучасних учених, які вивчали методологічні, теоретичні засади, шляхи оновлення педагогічної освіти (А. Алексюка, В. Андрущенка, А. Бойко, О. Дубасенюк, Н. Кузьміної, В. Лугового, В. Сластьоніна, Л. Хомич).

Підготовці педагогічних кадрів та становленню вищої освіти в Україні присвячені праці Л. Вовк, О. Глузмана, Н. Дем'яненко, М. Євтуха, М. Майбороди, І. Прокопенко, Б. Ступарика, О. Сухомлинської, М. Ярмаченка та ін.

Науково цінним у питанні фахової підготовки вчителя в історичному аспекті $€$ роботи таких дослідників: М. Гурець, І.Зайченко, С. Золотухіної, Л. Зеленської, М. Кузьміна, Н. Рудницької та ін..

Особливості професійно-педагогічної підготовки в учительських інститутах України (XIX-першої половини XXст.) знайшли відображення в дисертаційних дослідженнях I. Кравченко «Учительські інститути в системі підготовки педагогічних кадрів в Україні (друга половина XIX-початок XX ст.)», Л. Задорожної «Ідеї педагогічної майстерності в діяльності Глухівського учительського інституту (18741917)».

На основі вивчення історико-педагогічної літератури та архівних документів систематизовано теоретичні положення та узагальнено досвід організаційно-педагогічної діяльності Харківського державного учительського інституту для використання прогресивних надбань в умовах реформування вищої педагогічної освіти в Україні.

Вперше досліджено повоєнний період організаційно-педагогічної діяльності Харківського державного учительського інституту в системі вищої педагогічної освіти УРСР.

\section{V Висновки}

Підсумовуючи вище викладене, слід зауважити, що у повоєнний період навчальний рік було проведено значну і якісну роботу з забезпечення фуннціонування навчально-виховного процесу Харківського учительського інституту як окремої структурної одиниці. Організаційно-педагогічна діяльність цього навчального закладу здійснювалася за такими напрямами:

- навчальний (розроблення навчальних планів і підготовка навчальних програм);

- науково-дослідний (започатковано складання кандидатських іспитів, визначено теми науководослідних робіт викладачів та окремих кафедр, розпочата робота наукових гуртків);

- організаційний (здійснений набір студентів проти встановленої норми, облаштування учбових приміщень і бібліотеки);

- ідейно-виховний (літературні диспути, культпоходи до театру і кіно, розпочата робота гуртків і спортивних секцій);

- кадровий (відповідно до штатного розпису забезпечений викладачами).

\section{Бібліографрічні посилання}

[1] Дем'яненко Н.М. Загальнопедагогічна підготовка вчителя в Україні (XIX - перша третина XX ст.). Київ, 1998. 328 с.

[2] Дем'яненко H.М. Учительські інститути в системі в системі педагогічної освіти України (друга половина XIX- початок XX ст.) : монографія. Київ: Фенікс, 2010. 512 с.

[3] Кравченко І.М. Учительські інститути в системі підготовки педагогічних кадрів в Україні (друга половина XIX- початок XX ст.): автореф. дис. канд. пед. наук: спец. 13.00 .01 «Загальна педагогіка та історія педагогіки». Київ, 2008, 23 с.

[4] Майборода В.К. Вища педагогічна освіта в Україні: Історія, досвід, уроки (1917-1985 рр.). Київ: Вища школа, 1992. 196 c.

[5] Повоєнна Україна: нариси соціальної історії (друга половина 1940-х - середина 1950-х рр.): [колективна монографія] / відп. ред. В.М. Даниленко: у 3 ч. Ч. 3. Київ: Інститут історії України НАН України, 2010. 336 с.

[6] Сірополко С. Історія освіти в Україні. Київ: Наукова думка, 2001. 912 с.

[7] Учебные планы и программы, принятые в Киевском учительском институте. Сост. преподавателями института под. ред.директора ин-та К.М. Щербины. Киев, 1913. 136 с.

[8] ХОДА. Ф. Р-5007 «Харьковский государственный учительський інститут(1936-1945)», спр. 11

[9] ХОДА. Ф. Р-5007 «Харьковский государственный учительський інститут(1936-1945)», спр. 30

[10] ХОДА. Ф. Р-5007 «Харьковский государственный учительський інститут(1936-1945)», спр. 27

[11] ХОДА. Ф. Р-5707 «Харьковский государственный учительський институт (1946-1952)», спр. 16

[12] ХОДА. Ф. Р-5707 «Харьковский государственный учительський институт (1946-1952)», спр. 37 


\section{References}

[1] Demyanenko, N.M. (1998). General pedagogical teacher training in Ukraine (XIX - first third of XX century). Kyiv, 328 p.

[2] Demyanenko, N.M. (2010). Teacher Institutions in the System of Teacher Education of Ukraine (the second half of the nineteenth and early twentieth centuries): Monograph. Kyiv: Phoenix, 512 p.

[3] Kravchenko, I.M. (2008). Teachers' Institutions in the System of Teaching Personnel Training in Ukraine (second half of the XIX - early XX centuries): Author's abstract. dis Cand. ped Sciences: special 13.00.01 "General pedagogics and history of pedagogy". Kiev, 23 p.

[4] Mayboroda, V.K. (1992). Higher pedagogical education in Ukraine: History, experience, lessons (1917-1985 biennium). Kyiv: Higher school, $196 \mathrm{p}$.

[5] Danilenko, V.M. (Ed.) (2010). Postwar Ukraine: essays on social history (second half of the 1940s - mid-1950's): [Collective monograph]. Kiev: Institute of History of Ukraine of the National Academy of Sciences of Ukraine, $336 \mathrm{p}$.

[6] Siropolkko, S. (2001). History of education in Ukraine. Kyiv: Scientific Opinion, 912 p.

[7] Shcherbina, K.M. (Ed.) (1913). Curriculum plans and programs adopted at the Kiev Teachers' Institute. Sost. teachers of the institute under. Kyiv, $136 \mathrm{c}$.

[8] KRSA. F. R-5007 "Kharkiv State Teachers' Institute (1936-1945)", p. 11.

[9] KRSA. F. R-5007 "Kharkiv State Teachers' Institute (1936-1945)", p. 30.

[10] KRSA. F. R-5007 "Kharkiv State Teachers' Institute (1936-1945)", p. 27.

[11] KRSA. F. R-5707 Kharkiv State Teachers' Institute (1946-1952), p. 16.

[12] KRSA. F. R-5707 Kharkiv State Teachers' Institute (1946-1952), p. 37.

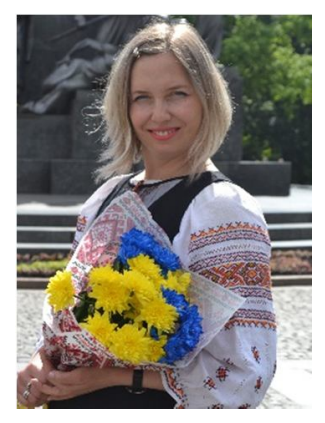

\section{Бондаренко Анна Станіславівна}

Аспірант кафедри загальної педагогіки та педагогіки вищої школи, Харківський національний педагогічний університет ім. Г.С. Сковороди, пров. Сурикова, 27, м. Харків, Україна, 61093.

Тел. +38(050) 630-23-44. E-mail: annabond.79@ukr.net

\section{Bondarenko Anna Stanislavivna.}

Post-graduated student of the Department of general pedagogy and pedagogy, H.S. Skovoroda Kharkiv National Pedagogical University, lane Surikova, 27, Kharkiv, Ukraine, 61093.

Phone: +38(050) 630-23-44. E-mail: annabond.79@ukr.net

ORCID: 0000-0001-7211-9471

\section{Citation (APA):}

Bondarenko, A. (2019). The organizational-pedagogical activity of the kharkiv state teachers' institute in the post-war period. Engineering and Educational Technologies, 7 (2), 30-37. doi: https://doi.org/10.30929/2307-9770.2019.07.02.03

\section{Цитування (ДСТУ 8302:2015):}

Бондаренко А. С. Організаційно-педагогічна діяльність харківського державного учительского інституту в повоєнний період / Інженерні та освітні технології. 2019. Т. 7. № 2. С. 30-37. doi: https://doi.org/10.30929/2307-9770.2019.07.02.03

Обсяг cmammi: сторінок - 8 ; умовних друк. аркушів - 1,159. 